\title{
ANALISIS LAPORAN ARUS KAS SEBAGAI DASAR PENGUKURAN LIKUIDITAS PADA PERUSAHAAN "UNICARE" CABANG MANADO
}

\author{
Chintia Debby Mogi ${ }^{1}$ \\ Agus.T.Poputra ${ }^{2}$ \\ Stanly. W. Alexander ${ }^{3}$ \\ Jurusan Akuntansi, Fakultas Ekonomi dan Bisnis, \\ Universitas Sam Ratulangi, Manado, 95115,Indonesia \\ email : Chintiamogi@gmail.com
}

\begin{abstract}
Cash flow statement is a summary of financial transactions related to cash, which depicts the historical changes in cash and cash equivalents classified into operating, investing their and funding during the period. Liquidity is an indicator of the kemampuam a company to pay all short-term financial obligations at maturity using liquid assets available. Therefore, cash flow greatly affect the measurement of liquidity, which in paying a short-term financial obligations indispensable good cash flow. Cash is the most dominant current assets in measuring the company's liquidity.
\end{abstract}

Keywords: Cash Flow, Liquidity

\section{PENDAHULUAN}

Setiap perusahaan pada awalnya hanya memikirkan keuntungan yang besar dan cepat dengan melakukan apapun untuk mencapai target yang diinginkan oleh perusahaan tanpa memikirkan dampak dimasa yang akan datang. Dalam rangka pengambilan keputusan, pengelola perusahaan memerlukan informasi khususnya informasi mengenai apa yang akan terjadi dimasa yang akan datang. Informasi yang cepat dan berkesinambungan berupa informasi akuntansi dalam bentuk laporan keuangan dapat membantu perusahaan untuk mengetahui keadaan dan kinerja ekonomi suatu perusahaan, Oleh sebab itu setiap perusahaan membutuhkan laporan keuangan untuk mendapatkan informasi khususnya informasi mengenai apa yang akan terjadi dimasa yang akan datang.

Menurut Garrin Noree n (2000; 744) mengemukakan bahwa, laporan arus kas (cash flows) adalah alat analisis yang sangat bermanfaat baik bagi manajer maupun kreditor, meskipun sebenarnya manajer lebih banyak memberikan perhatian terhadap arus kas (cash flows) yang disiapkan sebagai bagian dari proses penganggaran.

Laporan arus kas sering digunakan untuk menggambarkan kesanggupan perusahaan dalam memenuhi biaya operasional dan kewajiban perusahaan, agar menghasilkan keuntungan tambahan, perusahaan harus mempunyai kas untuk ditanamkan kembali. Arus kas mempunyai peranan yang cukup besar terhadap likuiditas perusahaan, Semakin besar aset lancar perusahaan berupa kas dibandingkan dengan seluruh kewajiban jangka pendek perusahaan berarti semakin tinggi juga tingkat likuiditas perusahaan dan begitu juga sebaliknya. Unicare Cabang Manado merupakan perusahaan yang bergerak dibidang penjualan barang dagangan dan jasa service. kas merupakan elemen yang terpenting didalam perusahaan untuk menunjang kegiatan operasional, oleh karena itu melalui analisa komponen arus kas, maka dapat diketahui bagaimana perusahaan mengelola dana yang dimilikinya dan kesanggupan perusahaan dalam memenuhi kewajibannya.

\section{Tujuan Penelitian}

Tujuan dari penelitian yang dilakukan adalah Menganalisis laporan arus kas dalam mengukur likuiditas pada perusahaan "Unicare" Cabang Manado. 


\section{Pengertian dan Fungsi Akuntansi}

\section{TINJAUAN PUSTAKA}

Menurut Sofyan (2004:10) akuntansi adalah bahasa atau alat komunikasi bisnis yang dapat memberikan informasi tentang kondisi keuangan berupa posisi keuangan yang tertuang dalam jumlah kekayaan hutang dan modal suatu bisnis dan hasil usahanya pada suatu periode tertentu.

\section{Pengelompokan Akuntansi}

Bidang Akuntansi sering disederhanakan menjadi dua kelompok yang disebut akuntansi keuangan dan akuntansi manajemen. Menurut Haryono Yusuf (2001:11) bahwa akuntansi keuangan adalah akuntansi yang bertujuan utama menghasilkan laporan keuangan untuk kepentingan pihak luar. Sedangkan akuntansi manajemen adalah akuntansi yang bertujuan utama menghasilkan informasi untuk kepentingan manajemen sebagai dasar pengambilan keputusan manajemen.

\section{Pengertian Laporan Keuangan}

Menurut Ikatan Akuntansi Indonesia dalam bukunya yang berjudul "Standar Akuntansi Keuangan“, Laporan keuangan yang lengkap biasanya meliputi neraca, laporan laba rugi, laporan perubahan posisi keuangan (yang disajikan dalam berbagai cara misalnya, laporan arus kas atau laporan arus dana), catatan dan laporan lain serta materi penjelasan yang merupakan bagian integral dari laporan keuangan. Dengan demikian laporan keuangan merupakan catatan informasi keuangan suatu perusahaan pada suatu periode akuntansi yang dapat digunakan untuk menggambarkan kinerja perusahaan tersebut. Laporan keuangan adalah bagian dari proses pelaporan keuangan.

\section{Laporan Arus Kas}

Laporan arus kas ini memberikan informasi yang relevan tentang penerimaan dan pengeluaran kas dari perusahaan dari suatu periode tertentu, dengan mengklasifikasikan transaksi berdasarkan pada kegiatan operasi, investasi dan pendanaan. Menurut Ikatan Akuntan Indonesia (2002;2.2) adalah : "Arus kas adalah arus masuk dan arus keluar kas setara kas ". Berdasarkan pengertian tersebut dapat diketahui bahwa arus kas merupakan jumlah kas yang mengalir masuk dan keluar dari suatu perusahaan dalam suatu periode tertentu. Dengan kata lain, arus kas adalah perubahan yang terjadi dalam jumlah kas perusahaan selama suatu periode tertentu.

\section{Tujuan Penyusunan Laporan Arus Kas}

Laporan arus kas merupakan suatu laporan yang berguna bagi manajer, investor, kreditur, dan pemakai lainnya dimana laporan tersebut dapat memberikan gambaran arus kas perusahaan sesuai dengan penggolongan aktivitasnya. Selain itu laporan arus kas juga berguna menjadi dasar untuk menilai kemampuan perusahaan dalam membayar hutangnya yang telah jatuh tempo. Laporan arus kas melaporkan pengiriman kas, pembayaran kas dan perubahan bersih pada kas yang berasal dari aktivitas operasi, investasi dan pendanaan dari suatu perusahaan selama satu periode dalam satu format yang merekonsiliasi saldo kas awal dan akhir. Laporan arus kas dengan demikian membantu menunjukkan bagaimana mungkin untuk melaporkan suatu rugi bersih dan tetap mengadakan pengeluaran modal yang besar atau membayar deviden.

\section{Klasifikasi Laporan Arus Kas}

Laporan arus kas harus melaporkan arus kas selama periode teretentu dan diklasifikasikan menurut Skousen

(2009 : 284):

1. Aktivitas Operasi

2. Aktivitas Investasi

3. Aktivitas Pendanaan

Aktivitas Operasi adalah aktivitas penghasil utama pendapatan perusahaan dan aktivitas lainnya yang bukan merupakan aktivitas investasi dan aktivitas pendanaan. Aktivitas Investasi adalah perolehan dan pelepasan aktiva jangka panjang serta investasi lain yang tidak termasuk setara kas. Aktivitas 
Pendanaan adalah aktivitas yangmengakibatkan perubahaan dalam jumlah atau komposisi modal dan pinjaman perusahaan.

Arus kas dari aktivitas operasi berhubungan dengan likuiditas karena didasarkan pada asumsi bahwa arus kas dari aktivitas operasi akan mempengaruhi aktiva lancar dan hutang lancar perusahaan. Hubungan Arus kas dari aktivitas investasi dengan likuiditas didasarkan pada asumsi bahwa jumlah arus kas dari aktivitas investasi dapat mempengaruhi perolehan dan pelepasan aktiva tetap. Sedangkan, hubungan antara arus kas dari aktivitas pendanaan dengan likuiditas didasarkan pada asumsi bahwa jumlah arus kas dari aktivitas pendanaan mempengaruhi jumlah modal dan hutang jangka panjang perusahaan.

Klasifikasi arus kas masuk dan arus kas keluar dengan aktivitas-aktivitasnya dapat dilihat pada gambar 2.1, dikutip dari Harahap, S, Sofyan. (2004)

\section{Klasifikasi Arus Kas Masuk dan Arus Kas Keluar \\ Aktivitas-Aktivitas \\ Arus Kas Masuk}

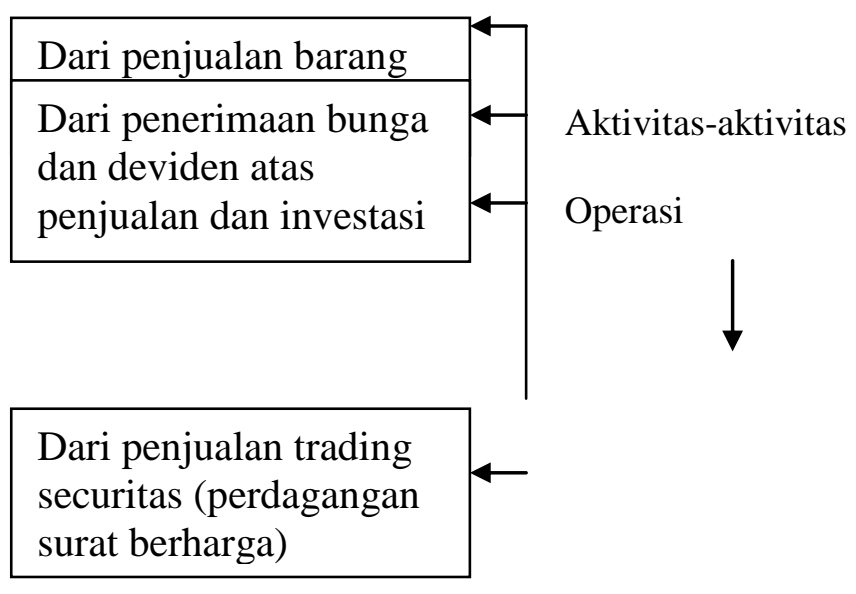

\section{Arus Kas Keluar}

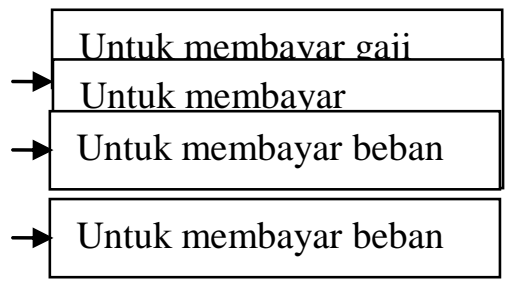

Untuk membayar bunga

Untuk membayar Pajak

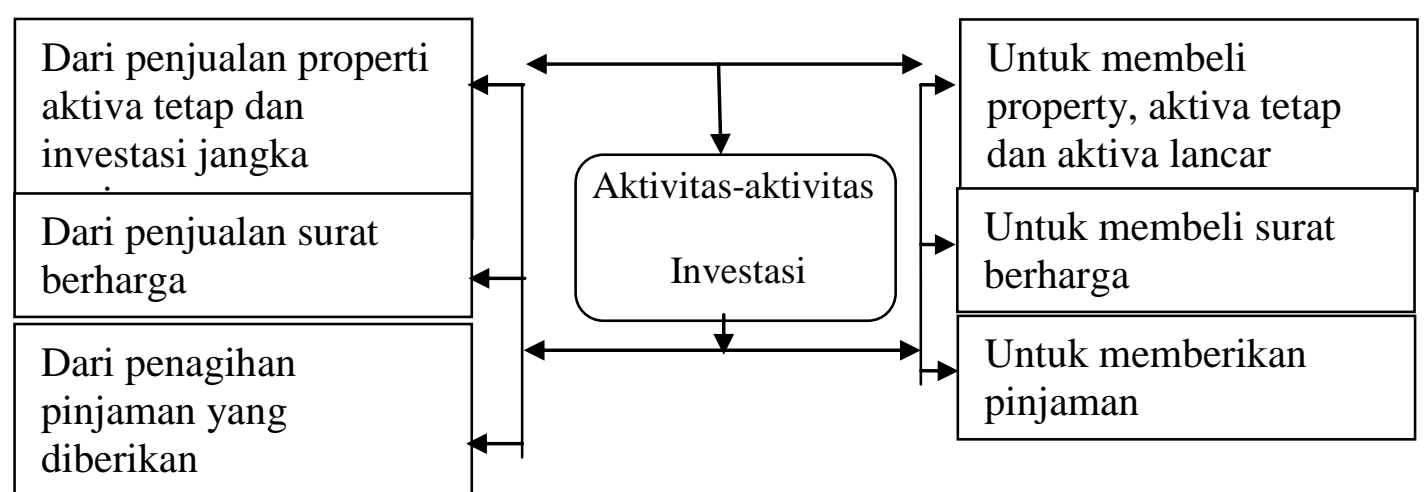

\begin{tabular}{|l|l|}
\hline $\begin{array}{l}\text { Dari penjualan saham } \\
\text { biasa atau saham } \\
\text { preferen }\end{array}$ \\
\hline $\begin{array}{l}\text { Dari penerbitan surat } \\
\text { utang }\end{array}$
\end{tabular}

Sumber : Dikutip dari, Harahap, S, Sofyan. 2004. Teori Akuntansi, 2004 


\subsubsection{Penyusunan Laporan Arus Kas}

Terdapat dua bentuk penyajian laporan arus kas, yang pertama metode langsung dan yang kedua metode tidak langsung. Metode langsung, Dengan metode ini, PSAK 2 mensyaratkan pengungkapan "kelompok utama penerimaan kas bruto dan pengeluaran kas bruto dan metode tidak langsung, dengan metode ini, arus kas dari aktivitas operasi ditentukan dengan menyesuaikan laba atau rugi neto dari pengaruh :

1. Pos-pos non kas (misalnya penyusutan)

2. Pos-pos yang berkaitan dengan arus kas investasi atau pendanaan (misalnya laba penjualan asset tetap) dan,

3. Perubahan modal kerja operasi (misalnya perubahan persediaan, piutang dagang, dan utang dagang).

\section{Likuiditas}

Likuiditas merupakan suatu indikator mengenai kemampuan perusahaan untuk membayar semua kewajiban finansial jangka pendek pada saat jatuh tempo dengan menggunakan aktiva lancar yang tersedia. Likuiditas diukur dengan rasio aktiva lancar dibagi dengan kewajiban lancar. Likuiditas perusahaan berperan cukup penting dalam kelangsungan perusahaan, perusahaan yang tidak dapat mencapai tingkat likuiditas yang baik akan membuat kepercayaan pihak eksternal perusahaan khususnya kreditur untuk memberikan pinjaman kepada perusahaan, hal ini juga mengakibatkan menurunnya kemampuan perusahaan untuk mengembangkan usahanya.

Rasio likuiditas mengukur kemampuan likuiditas jangka pendek perusahaan dengan melihat aset lancar perusahaan yang relatif dengan utang lancarnya, utang dalam hal ini merupakan kewajiban perusahaan. Likuiditas merupakan biaya yang ditanggung pemodal jika ingin menjual sekuritasnya secara cepat.

Adapun formula untuk menghitung rasio likuiditas menurut Kieso (2002:493) adalah :

\begin{tabular}{|lc|}
\hline Current Cash Debt Ratio $=$ & $\begin{array}{c}\text { Kas bersih yang disediakan } \\
\text { Oleh aktivitas operasi }\end{array}$ \\
\cline { 2 - 2 } & Kewajiban lancar rata-rata \\
\hline
\end{tabular}

\section{Analisis Arus Kas Sebagai Dasar Pengukuran Likuiditas}

Analisis terhadap arus kas sering digunakan untuk menggambarkan kesanggupan perusahaan dalam memenuhi biaya operasional dan kewajiban perusahaan. Arus kas mempunyai peranan yang cukup besar terhadap likuiditas perusahaan. Semakin besar aset lancar perusahaan berupa kas dibandingkan dengan seluruh kewajiban jangka pendek perusahaan berarti semakin tinggi juga tingkat likuiditas perusahaan dan begitu juga sebaliknya. Untuk meminimalisasikan gangguan terhadap tingkat likuiditas perusahaan perlu dibuat suatu perkiraan untuk menghindari masalah-masalah yang mungkin timbul dan mempengaruhi tingkat likuiditas perusahaan.

Dalam menganalisis kekuatan keuangan perusahaan, umumnya para analis menggunakan informasi dari dua laporan keuangan dasar yaitu neraca dan laporan laba rugi sebagai dasar pengukurannya. Dengan demikian dapat kita ketahui bahwa terdapat pengaruh arus kas terhadap likuiditas perusahaan, namun jika dinilai secara komponen dari arus kas operasi, investasi dan pendanaan, hanya arus kas dari aktivitas pendanaan yang memiliki pengaruh signifikan terhadap likuiditas.

\section{METODE PENELITIAN}

\section{Jenis Data}

Jenis data yang dipakai dalam penelitian ini adalah data kuantitatif pada perusahaan "Unicare" Cabang Manado., dimana menurut Kuncoro (2003:124), data kuantitatif diambil dalam bentuk angka yaitu laporan keuangan dan data dapat diukur dalam suatu skala Numberik (Angka), Misalnya; harga saham, besarnya pendapatan, dan lain-lain.

\section{Sumber Data}


Sumber data menurut cara memperolehnya, antara lain:

1. Data Primer (primary data) adalah data yang dikumpulkan sendiri oleh perorangan/ suatu organisasi secara langsung dari objek yang diteliti dan untuk kepentingan studi yang bersangkutan yang dapat berupa interview, observasi.

2. Data Sekunder (secondary data) adalah data yang diperoleh/ dikumpulkan dan disatukan oleh studi-studi sebelumnya atau yang diterbitkan oleh berbagai instansi lain. Biasanya sumber tidak langsung berupa data dokumentasi dan arsip-arsip resmi.

\section{Teknik Pengumpulan Data}

Dalam penelitian yang dilakukan, maka data diperoleh dengan menggunakan teknik pengumpulan data yaitu sebagai berikut :

1. Metode wawancara yaitu penulis mengumpulkan data dengan mewawancarai pihak yang terkait dari Perusahaan "Unicare" cabang manado.

2. Observasi yaitu penulis mengamati langsung laporan arus kas, laporan laba-rugi dan kelengkapan lainnya.

3. Penelitian Kepustakaan (Library Research), yaitu untuk memperoleh informasi dengan mempelajari buku- buku yang berhubungan dengan masukan yang akan dibahas atau diteliti untuk digunakan sebagai dasar teori yang melengkapi proses penyusunan skripsi ini.

4. Media elektronik (Electronic Media), yaitu lewat internet untuk melengkapi proses penyusunan skripsi ini.

\section{Sejarah Singkat perusahaan}

\section{HASIL PENELITIAN}

Unicare IT Service Solution merupakan salah satu divisi usaha dari PT. Daxell Multi Solusi yang berkedudukan di Manado, Sulawesi Utara. Dahulu sebelumnya Unicare bernama RC'Comp, untuk melegalkan usaha yang dijalankan, maka pada tanggal 13 April 2011, dengan resmi RC'Comp terdaftar dengan nama PT. Daxell Multi Solusi, dengan nomor TDP 180614700405. Unicare hadir untuk menawarkan solusi dan memberikan layanan purna jual untuk permasalahan dalam bidang IT. Di bawah payung PT. Daxell Multi Solusi, yang sudah lama berkecimpung dalam bidang IT, Unicare IT Service Solution didukung dengan pengalaman dan jaringan kerja yang luas, untuk melayani kebutuhan dan mengatasi permasalahan costumer dengan handal dan profesional. Adapun alamat dari Unicare Jl. Boulevard, Kawasan Mega Mas sebagai tempat service centre (Lenovo, Asus, Fujitsu, Advan, dsb) dan sebagai Training Centre memiliki luas 160m2, 4 lantai, dengan status milik perusahaan. Jumlah karyawan 7 orang.

\section{Analisis Laporan Arus Kas Sebagai Dasar Pengukuran Likuiditas}

Analisis terhadap arus kas sering digunakan untuk menggambarkan kesanggupan perusahaan dalam memenuhi biaya operasional dan kewajiban perusahaan. Arus kas mempunyai peranan yang cukup besar terhadap likuiditas perusahaan. Semakin besar aset lancar perusahaan berupa kas dibandingkan dengan seluruh kewajiban jangka pendek perusahaan berarti semakin tinggi juga tingkat likuiditas perusahaan dan begitu juga sebaliknya. Untuk meminimalisasikan gangguan terhadap tingkat likuiditas perusahaan perlu dibuat suatu perkiraan untuk menghindari masalah-masalah yang mungkin timbul dan mempengaruhi tingkat likuiditas perusahaan

\section{Pembahasan}

Adapun masalah-masalah yang akan dianalisa dan dievaluasi adalah sebagai berikut:

1. Sumber Kas Perusahaan

2. Penggunaan Kas Perusahaan

3. Analisa Laporan Arus Kas

4. Tingkat Likuiditas perusahaan

Dengan data yang diambil dari perusahaan maka penulis membuat laporan arus kas periode 2013 Perusahaan Unicare sebagai bahan analisis untuk skripsi yang dibuat ini. Informasi yang didapat penulis 
laporan arus pada Unicare Cabang Manado, pertama kali digunakan pada tahun 2008, dan masih dalam konsep yang sederhana. Dan metode yang dipakai adalah metode langsung.

\section{Sumber Kas yang berasal dari aktivitas operasi}

Jumlah masing-masing sumber kas yang berasal dari aktivitas operasi adalah sebagai berikut, Total sumber kas pada periode 2013 sebesar Rp.282.893.920, Laba bersih senilai Rp.52.684.072, Penyusutan Aktiva tetap senilai Rp.192.209.848. Jika dibuat berdasarkan rumusnya maka Laba bersih/Total Kas dikali 100\% hasilnya $18.62 \%$. Begitupun pada penyusunan Aktiva Tetap/Total kas dikali $100 \%$ hasilnya $67.94 \%$

\section{Sumber Kas yang berasal dari aktivitas Pendanaan}

Terdapat sumber kas dari aktivitas pendanaan yaitu penambahan kas (modal disetor) pada bulan oktober 2013 sebesar Rp.380.000.000

\section{Sumber Kas yang berasal dari aktivitas Investasi}

Terdapat penambahan modal saham sebesar Rp. 1.110.100.008 dan pembelian pembangkit listrik sebesar Rp.7.000.000 pada periode 2013. Dan ini menguntungkan perusahaan Unicare sehingga Unicare pada periode 2013 sudah dapat mengatasi setiap kesulitan keuangan, dan sudah bisa membayar hutang jangka pendeknya maupun jangka panjangnya.

\section{PENUTUP}

\section{Kesimpulan}

Dari hasil penelitian yang dilakukan penulis dengan hasil analisis dan evaluasi terhadap laporan keuangan Unicare Cabang Manado, maka dapat ditarik kesimpulan sebagai berikut;

1. Unicare pada periode 2013 sudah dapat mengatasi setiap kesulitan keuangan, dan sudah bisa membayar hutang jangka pendeknya maupun jangka panjangnya, ini bisa dilihat pada analisis laporan arus kas yang dibuat oleh penulis dengan meneliti data-data dari perusahaan. Berdasarkan perhitungan yang dibuat dengan jelas kemampuan perusahaan untuk memeuhi kewajiban jangka pendeknya sudah terlaksana, dan sesuai dengan judul skripsi yang diambil oleh penulis.

2. Teknik Manajemen yang dipakai perusahaan selama tahun 2013 bisa menjadi motivasi bagi penulis kedepan apabila dalam mengelolah manajemen perusahaan, itu bisa dilihat dalam Bab IV, dimana Unicare mampu melewati kesulitan keuangan.

3. Efisiensi kas selama tahun 2013 dapat menutupi setiap kerugian pada tahun 2012 dengan penambahan uang kas dan saham yang ada. Bahkan setiap kebijakan baru dari perusahaan mampu menambah kinerja perusahaan termasuk dalam peningkatan likuiditas perusahaan.

\section{Saran}

Adapun Saran-saran yang dapat diberikan atas hasil penelitian yang dilakukan oleh penulis yaitu sebagai berikut;

1. Bagi perusahaan, teknik manajemen yang dipakai perusahaan pada tahun 2013 harus dipertahankan agar bisa meningkatkan laba, dan perlunya efisiensi kas untuk menghindari kerugian, dengan demikian perusahaan dapat lebih berkembang.

2. Bagi generasi selanjutnya, dalam menyusun skripsi harus lebih menerapkan ilmu yang didapat selama proses belajar dalam melakukan penelitian nanti. 


\section{DAFTAR PUSTAKA}

Al. Haryono Yusup, Dasar-dasar Akuntansi, Penerbit VPP AMP YKPN, Yogyakarta 2001.

Bambang Riyanto. 1998, Dasar-dasar Pembelanjaan Perusahaan. BPFE Yogyakarta, Yogyakarta.

Dito Alief, Analisis laporan arus kas untuk mengukur likuiditas pada PT. Kimia Farma (persero), tbk,

Garrison, Ray. H, \& E.W. Noreen, 2000, Alih bahasa A. Totok Budisantoso, Akuntansi Manajerial, Edisi kesembilan, PT. Salemba Empat, Jakarta.

Harahap, Sofyan Syafri, 2004., Analisis Kritis Atas Laporan Keuangan, Cetakan keempat, PT. Raja Grafindo Persada, Jakarta

Heiby Sanger, 2015, Analisis informasi laporan arus kas sebagai alat Ukur efektivitas kinerja keuangan pada pt. Gudang Garam tbk. Sebagai salah satu perusahaan industry Rokok yang terdaftar di bursa efek Indonesia, Fakultas Ekonomi Jurusan Akuntansi Universitas Sam Ratulangi Manado

Henry Simamora, 2000, Akuntansi : Basis Pengambilan Keputusan Bisnis, Cetakan Pertama Jilid 2, Penerbit : Salemba Empat, Jakarta.

Horngren, C, Harrison. W, and Bamber. L, 2002, Akuntansi, Jilid 1, Edisi kelima, PT. Indeks, Jakarta

Ikatan Akuntan Indonesia. 2009, Pernyataan Standar Akuntansi Keuangan, No.2 Laporan Arus Kas (Revisi 2009), Jakarta Salemba Empat.

James Marcel Kaunang, 2013, Analisis laporan arus kas sebagai alat ukur menilai kinerja pada

Pt. Pegadaian (persero) cabang manado timur, Fakultas Ekonomi Jurusan Akuntansi

Universitas Sam Ratulangi Manado

John Downes, Jordan Elliot Goodman, 1999 Dictionary Of Finance And Investment Terms United States Of America : Barron's,

John J Wild, 2005, Analisis Laporan Keuangan, Buku Satu, Edisi Delapan, PT. Salemba Empat, Jakarta

Kasmir, 2008. Analisis Laporan Keuangan, Rajawali Pers, Jakarta.

Lukman Syamsuddin. 2002, Manajemen Keuangan Perusahaan, Edisi Baru, Cetakan Ketujuh, Raja Grafindo Persada, Jakarta

Mulyadi, 2001, Akuntansi Manajemen: Konsep, Manfaat, dan Rekayasa, Edisi ketiga, PT. Salemba Empat, Jakarta

Pardhy, S, 2013, Analisis Arus Kas Terhadap Likuiditas Perusahaan pada PT.Pertani (Persero) Makasar, Universitas Hassanudin Makasar

Sadeli.H, Lili.M, 2002, Dasar-dasar Akuntansi. Cetakan kelima, PT.Bumi Aksara, Jakarta

S. Munawir, 2004, Analisa Keuangan, Liberty Yogyakarta, Jakarta

Sugiyono, 2002, Metode Penelitian Bisnis, CV Alfabeta, Bandung.

Subani, 2015, Analisis arus kas untuk mengukur kinerja keuangan (studi pada kud sido makmur lumajang), STIE Widya Gama Lumajang

Vera Tatengkeng, Steven Tangkuman, 2015, Analisis kinerja laporan keuangan pt. Bank sulut (persero) tbk periode 2009-2013 tahun, Fakultas Ekonomi Jurusan Akuntansi Universitas Sam Ratulangi Manado

Queen Laurent FFS, 2013, Analisis laporan arus kas sebagai alat ukur likuiditas kinerja keuangan pada pt. swakarya indah busana. Program Studi Akuntansi Fakultas Ekonomi, Universitas Maritim Raja Ali Haji Tanjungpinang 